\title{
Konur og stjórnarhættir fyrirtækja á Íslandi
}

\section{Margrét Sæmundsdóttir}

Ágrip: Félög sem hafa stjórnarmenn af báðum kynjum eru af mörgum talin skila betri arðsemi en pau félög sem hafa einsleitar stjórnir. Konur í vestrænum löndum eiga pó ekki nema að meðaltali um 15\% sæta í stjórnum fyrirtækja en margar skýringar hafa komið fram á pessu misræmi milli kynjanna. Í pessari rannsókn er gerð athugun á pví hvort íslensk fyrirtæki sem hafa bæði kynin í stjórn séu líklegri til pess að skila meiri arðsemi en fyrirtæki sem eru með einsleitar stjórnir. Enn fremur er leitast við að skýra annars vegar hvort að konur sem sitja í stjórn hafi áhrif á stjórnarhætti innan fyrirtækis hvað varðar starfsmenn og hins vegar hvort að fleiri konur séu stjórnendur innan fyrirtækja par sem konur sitja í stjórn eða öfugt, p.e. að fyrirtæki sem hafa fleiri kvenstjórnendur auki hlut kvenna í stjórnum. Gerð var athugun á 101 fyrirtæki í pessu samhengi. Niðurstöðurnar benda til pess að pað sé jákvætt marktækt samband milli pess að hafa bæði kynin í stjórn fyrirtækis og arðsemi eigin fjár og veikt en jákvætt samband við arðsemi heildareigna. Hins vegar komu engin tengsl fram pegar skoðað var hvort seta kvenna í stjórnum leiddi til fleiri kvenna í stjórnendastöðum og betri stjórnarhátta með tilliti til starfsmanna.

Lykilorð: fjölbreytni; konur; arðsemi; stjórnarhættir; stjórnir; stjórnendur

\begin{abstract}
It is often said that gender diversity on corporate boards is positively related to firm performance. Yet women in Western countries hold only about 15 percent of board seats, on average. There are many potential explanations for this gender imbalance. This study investigates whether Icelandic companies who have members of both genders on their boards are likely to be more profitable than companies whose boards lack gender diversity. As well, it attempts to examine whether women who sit on boards have an influence on firms' corporate governance and employee satisfaction, and whether there is a relationship between the number of women on boards and the number of women in top management positions. 101 companies were investigated. The results suggest that there is a statistically significant positive relationship between having members of both genders on the board of a company and its returns on equity, and a weak but positive relationship to companies' returns on assets. On the other hand, the data did not support the hypotheses that women's presence on corporate boards leads to a greater number of women in management positions or to better corporate policies towards employees.
\end{abstract}

Keywords: diversity; women; performance; corporate governance; board; top management 


\section{Inngangur}

Í febrúar 2009 gaf OECD út ályktun um áhrif stjórnarhátta fyrirtækja (e. corporate governance) á fjármálakreppuna. Í ályktuninni kemur m.a. fram að mistök og veikleiki hafi einkennt stjórnarhætti fyrirtækja par sem ekki hafi verið gætt nægilega vel að pví að draga úr of mikilli áhættu í fjármálaviðskiptum og óhóflegum póknunum til stjórnarmanna og æðstu stjórnenda fyrirtækja. Pessi ályktun á vel við íslenska viðskiptalífið en ofan á pað má segja að stjórnarhættir fyrirtækja hér á landi hafi einkennst af einsleitum stjórnum, miklum krosseignatengslum og fámennum hópi valdamanna með persónuleg tengsl sín á milli.

Í endurreisninni á fjármálakerfinu sem nú fer fram hér á landi eins og víða annars staðar í heiminum er mikilvægt að nota tækifærið og endurmeta og bæta stjórnarhætti fyrirtækja. Umræðan um bætta stjórnarhætti er pó ekki ný af nálinni. Á síðustu tíu árum hafa komið upp nokkur stór hneyksli og svikamál í rekstri fyrirtækja sem hafa ekki einungis skaðað fjárfesta heldur líka samfélagið. Pað hefur orðið til pess að fleiri fræðimenn hafa komið fram og birt greinar um hvernig megi innleiða betri leiðir að góðum stjórnarháttum. Ein af peim leiðum er að tryggja að stjórn sé skipuð fjölbreyttum hópi einstaklinga vegna pess að slík stjórn er alla jafna talin gefa betri afkomu pegar til lengri tíma er litið. Skilgreina má fjölbreytni annars vegar út frá pví hverjir mynda stjórnina s.s að bæði kynin taki virkan pátt í stjórn fyrirtækis, einstaklingar sem sitja í stjórn hafi ólíkan menningarlegan uppruna, reynslu og/eða menntun og pekkingu. Hins vegar má skilgreina fjölbreytni út frá tilgangi hennar og áhrifum, p.e. hverju hún eigi að skila fyrirtækinu. Í pessari grein er eingöngu fjallað um kynin í merkingunni fjölbreytni og áhrif sem pau kunna að hafa á stjórn fyrirtækja.

Margar rannsóknir hafa verið gerðar á stjórnunarstíl eða hegðun kynjanna í forystuhlutverki innan fyrirtækja. Flestar peirra benda til pess að kynin hegði sér á keimlíkan hátt en pó megi greina mun á milli kynjanna pegar kemur að ákvarðanatöku. Konur virðast vera líklegri en karlar til að hika pegar kemur að stórum ákvörðunum, p.e. pær eru gjarnari á að vilja spyrja fleiri spurninga og greina málin niður í smæstu einingar áður en ákvörðun er tekin. Мeð öðrum orðum er hér átt við að konur séu áhættumeðvitaðri en karlmenn. Að sama skapi hefur talsvert verið skrifað um að aukinn hlutur kvenna í stjórnum muni sjálfkrafa leiða til aukinnar pátttöku kvenna í stjórnendastöðum eða að aukinn fjöldi kvenna í stjórnendastöðum muni auka framgang kvenna í stjórn fyrirtækja. Gögn frá m.a. Bandaríkjunum, Bretlandi og Kanada ${ }^{1}$ hafa pó ekki greint petta samband heldur sýnt pvert á móti, að prátt fyrir að konum hafi fjölgað í æðstu forystuhlutverkum á síðustu áratugum hefur fjölgun peirra verið mun hægari en hjá karlmönnum. Pykir pað einkum skjóta skökku við par sem konur eru helmingur alls vinnuafls á Vesturlöndum og fleiri konur hafa lokið háskólagráðu en karlmenn í mörgum pessara landa, p.m.t. á Íslandi.

1 Anastasopoulos, Brown og Brown, 2002. 
Á síðustu árum hafa síðan birst rannsóknir á tengslum arðsemi og kynjahlutfalla í stjórnum fyrirtækja og sýna margar peirra að fyrirtæki sem hafa bæði kynin í stjórn skili betri arðsemi en pau fyrirtæki sem hafa einsleitar stjórnir. Рað eru hins vegar líka til rannsóknir sem gefa enga vísbendingu um tengsl milli pessara pátta en nánast engar peirra, svo vitað sé, finna neikvæð tengsl.

Megintilgangur pessarar rannsóknar er að reyna að greina hvort stjórnir par sem konur eiga sæti , hafi áhrif á stjórnarhætti og arðsemi fyrirtækja. Par sem flestir eru sammála um að stjórn skipti máli er eðlilegt að spyrja sig að pví hvað pað er sem parf að skoða í sambandi við hana. Ef pað skiptir til dæmis máli að konur séu í stjórn, ekki eingöngu fyrir pað að pær eru konur, heldur vegna pess að pær hafa áhrif er mikilvægt fyrir hluthafa í pessu samhengi að tryggja aðkomu peirra.

Rannsóknin var unnin af viðskiptaráðuneytinu með styrk frá Rannsóknasetri vinnuréttar og jafnréttis við Háskólann á Bifröst. Hugmyndin að pessari rannsókn kviknaði pegar Rannsóknasetrið var að undirbúa ráðstefnu um nýtingu mannauðs í stjórnun fyrirtækja sem lokaáfanga verkefnisins um jafnréttiskennitöluna í samstarfi við viðskiptaráðuneytið og aðra aðila. ${ }^{2}$ Notaðar eru fyrirmyndir frá erlendum rannsóknum við vinnslu gagna. ${ }^{3}$ Greinin skiptist að öðru leyti upp með eftirfarandi hætti: Eftir inngangi er í öðrum hlutanum fjallað um kenningar um stjórnarhætti í tengslum við fjölbreytni í stjórn fyrirtækja. Í priðja hlutanum er sagt frá stöðu kynja í stjórnum fyrirtækja og í fjórða hlutanum er gerð grein fyrir fyrrnefndri rannsókn um áhrif kvenna á stjórnarhætti og arðsemi fyrirtækja. Að lokum eru dregnar saman niðurstöður.

Vert er að geta pess að rannsóknin var unnin fyrir hrun fjármálakerfisins sem átti sér stað hér á landi í byrjun október 2008. Landslagið er pví að breytast gagnvart stjórnum m.a. með tilliti til eignarhalds ríkisins á premur bönkum, hugsanlegrar sampjöppunar fyrirtækja og fjölgunar gjald prota.

\section{Stjórnir og stjórnendur}

Í stærri fyrirtækjum er mjög kostnaðarsamt og nánast ómögulegt að tryggja beina aðkomu hluthafa að öllum ákvörðunum um rekstur fyrirtækis. Рað leiðir til pess að hluthafar sem eru jafnframt eigendur verða að stofna félag og framselja ákvarðanavaldið til nokkurra valinna eða kosinna einstaklinga. Pessir einstaklingar mynda stjórn og fela síðan æðstu stjórnendum í fyrirtækinu að annast daglegan rekstur. Stjórnin er pví tengiliður milli stjórnenda og eigenda og gegnir lykilhlutverki í að

2 Auk viðskiptaráðuneytisins voru iðnaðarráðuneytið, Samtök atvinnulífsins, Félag kvenna í atvinnurekstri, Jafnréttisráð og Jafnréttisstofa aðilar að samstarfinu. Geta má pess að ráðstefnan var haldin í september 2008.

3 Rannsóknin byggist m.a. á rannsóknum Jurkus, Park og Woodard, 2008; Smith, Smith og Verner, 2005; Randøy, Thomsen og Oxelheim, 2006; Catalyst, 2007; Carter, Simkins og Sampson, 2002; Rose, 2005.

4 Birgir Már Ragnarsson, 2004. 
taka ákvarðanir um framtíð fyrirtækisins. Petta framsal veldur hins vegar oft togstreitu milli stjórnar og/eða stjórnenda annars vegar og eigenda hins vegar sem almennt er nefnt umboðsvandi (e. agency problem). Pessi vandi getur komið til vegna ólíkra hagsmuna á milli pessara aðila. Раð leiðir gjarnan til óhagræðis og kostnaðar sem er kallaður umboðskostnaður (e. agency cost). Kostnaður getur fallið til vegna pess að stjórnin lætur sína persónulegu hagsmuni ráða á kostnað hluthafanna t.d. með pví að taka of mikla áhættu í fjárfestingu í samvinnu við æðstu stjórnendur eða án peirra. Á sama hátt getur kostnaður fallið til vegna pess að stjórnin veitir stjórnendum ekki nægjanlegt eftirlit og aðhald í rekstri eins og hvað varðar laun sem stjórnendur skammta sjálfum sér og/eða vegna annarra rekstrarútgjalda sem leiða ekki endilega til verðmætis fyrir hluthafana pegar litið er til lengri tíma. Рað ætti pví að skipta hluthafa miklu máli hverjir eru valdir til pess að stjórna fyrirtækinu annars vegar og að fyrirtækið búi yfir góðum stjórnarháttum hins vegar svo tryggja megi að verið sé að hámarka hag peirra.

Í rannsóknum Carter, Simkins og Simpson (2003) og Francoeur, Labelle og Sinclair-Desgagné (2007) er bent á pað sjónarmið að styrkja megi stjórnarhætti fyrirtækis og draga um leið úr umboðsvandanum og kostnaðinum með pví að jafna hlut kvenna og karla í stjórnum fyrirtækja. Nokkur dæmi eru nefnd pessu til stuðnings. Í fyrsta lagi hafa kynin ólíka sýn og pekkingu á neytendum sem skiptir máli í flóknu viðskiptaumhverfi. Fleiri hugmyndir og upplýsingar eru pví líklegri til að spretta upp en hjá einsleitum stjórnum. Í öđru lagi er talið að pegar bæði kynin eru í stjórn auki pað á sjálfstæði stjórnarmanna, ${ }^{5}$ p.e.a.s. peir séu líklegri til pess að spyrja fleiri spurninga og eiga í skoðanaskiptum. Allar ákvarðanir eru pví betur ígrundaðar sem styrkir samkeppnishæfni fyrirtækja pegar til lengri tíma er litið. Í priðja lagi má nefna að fyrirtæki sem halda úti virkri stefnu um jafna stöðu kynja eru talin líklegri til pess að bæta viðhorf og ímynd sína út á við gagnvart neytendum og fjárfestum. Að lokum eiga fyrirtæki sem hafa tileinkað sér slíka ímynd auðveldara með að laða til sín hæfari starfsmenn af báðum kynjum. ${ }^{6}$ Rökin sem eru gjarnan notuð gegn ofangreindum sjónarmiðum, s.s. í rannsókn Hambrick, Cho og Chen (1996), eru pauað einmitt vegna pess að kynin eru ólík eigi pau til að skapa vanda og ágreining í fyrirtækjum. Ekki er pó verið að efast um að bæði kynin geti skapað nýjar hugmyndir heldur er vandinn sá að pað gengur hægt að taka ákvarðanir vegna óskilvirkrar teymisvinnu sem bitnar á fyrirtækjum, sérstaklega meðal peirra sem keppa á mjög hröðum samkeppnismarkaði. Pannig er litið á, að pó að ávinningur sé af nákvæmari greiningum pegar litið er til lengri tíma er pað ekki talið bæta upp pann neikvæða kostnað og skaða sem fylgir töfinni fyrir ákvörðuninni. Önnur sjónarmið sem hafa verið notuð til pess að styðja við aukinn hlut kvenna í stjórn fyrirtækja tengist hagsmunakenningunni (e. stakeholder theory) sem gerir ráo fyrir pví að pað sé bæði táknrænt og markmið í sjálfu sér að skipa konu í stjórn jafnvel pótt ekkert samband finnist á milli

5 Sjá einnig rannsóknir Mace, 1971 og Dewatripoint, Jewitt og Tirole, 1999.

6 European Commission, 2003. 
kyns og arðsemi fyrirtækisins. Eina sem parf að gera í pessu samhengi er að hagsmunaaðilar sem geta verið t.d. stjórnmálamenn, samtök, stjórnendur eða starfsmenn prýsti á fyrirtækin að fjölga konum vegna pess að peir meta pátttöku kvenna og kvenlæg gildi innan fyrirtækja. ${ }^{7}$

\section{Staða kynja í stjórnum fyrirtækja}

Á undanförum árum hefur konum fjölgað í stjórnum fyrirtækja bæði hérlendis og erlendis. Fjölgun kvenna innan stjórna hefur pó verið mjög hæg og eru karlmenn enn í miklum meirihluta í flestum löndum heims. Sem dæmi má nefna að konur voru að meðaltali í kringum 15\% af heildarfjölda stjórnarmanna meðal stærstu félaga á Vesturlöndum á árinu 2007. Samkvæmt upplýsingum frá Jafnréttiskennitölunni fyrir árið 2007, skipuðu konur 8\% af stjórnarsætum sem er fækkun frá pví á árinu 2005 en pá skipuðu konur um 12\% stjórnarsæta. ${ }^{9}$ Hagstofa Íslands tekur saman fjölda kvenna og karla í stjórnum og æðstu stjórnendastöðum í öllum hlutafélögum. Á árinu 2007 voru 22\% kvenna í stjórn og 19\% í æðstu stjórnunarstöðum. ${ }^{10}$ Bandaríkin og Kanada eru að jafnaði talin hafa náð bestum árangri hvað varðar fjölgun kvenna í stjórnum í skráðum félögum. Ísland hefur pó mælst í efri mörkum á Vesturlöndum en í neðri mörkum í samanburði við hin Norðurlöndin. Noregur trónir á toppnum en geta má pess að par í landi er stór eignarhluti í mörgum stærstu fyrirtækjum í eigu ríkisins. Eins var lögfest í byrjun árs 2008 ákvæði í norskum lögum um kynjakvóta í stjórn fyrirtækja par sem kveðið er á um að konur skuli að minnsta kosti vera 40\% af stjórnarmönnum í hlutafélögum sem skráð eru par í landi.

Með hliðsjón af pví að konur eru helmingur vinnuafls á Vesturlöndum og fleiri konur eru með háskólagráðu en karlmenn í mörgum pessara landa, par á meðal á Íslandi, er eðlilegt að spyrja hvað valdi pví að konur eru ekki jafnmargar og karlmenn í stjórnum fyrirtækja og í æðstu stjórnendastöðum. Erfitt er að henda reiður á pví en margar skýringar hafa komið fram á síðustu árum. Ein peirra er að konur reki sig enn á hið svokallaða glerpak (e. glass ceiling). Með glerpaki er átt við ósýnilegan múr eða hindranir sem varna pví að hæfir einstaklingar nái að próast innan skipulagsheildar sinnar. Slíkar ósýnilegar hindranir eru sagðar vera til staðar fyrir konur í mörgum fyrirtækjum og koma í veg fyrir að pær nái eins langt og pær gjarnan vildu. ${ }^{11}$ Önnur pekkt skýring sem hefur verið nefnd er að konur hafi takmarkað aðgengi að tengslanetum vegna skorts á sýnileika og trausti. Pegar leitað er að aðilum til að taka sæti í stjórnum hafa leitarskilyrðin oftar en ekki verið pröng og ólíklegra

7 Fields og Keys, 2003, bls. 12.

8 Sjá Sealy, Obe og Singh, 2008 og Catalyst, 2008. Hafa verður í huga að samanburður milli landa gefur ekki alltaf rétta mynd par sem aðferðafræðin á bak við söfnun gagna er mismunandi s.s. hvað varðar stærð fyrirtækja, aldur peirra o.s.frv.

9 Jafnréttiskennitalan, 2008.

10 Hagstofa Íslands, 2008.

11 Milkovich og Boudreau, 1997. 
að konur en karlar falli að peim skilyrðum sem hefð er fyrir að setja. ${ }^{12}$ Margir, m.a. Catalyst (alpjóðleg rannsóknarstofnun í kvennafræðum), hafa bent á að lausnin til pess að auka sýnileika kvenna og brjóta glerpakið sé að innleiða mentorkerfi fyrir stjórnendur. Markmiðið með slíku kerfi er að pjálfa stjórnendur til pess að ná betri árangri við stjórnun og kynna pá út á við svo peir eigi meiri möguleika á að komast í stjórnir fyrirtækja. Að auki hafa fyrirtæki verið hvött til pess að stytta m.a. vinnutíma og koma pannig til móts við fjölskylduskuldbindingar stjórnenda. Pá eru ýmsir á peirri skoðun að ef fjölga á konum í stjórnum purfi pær að fara fyrir meira fé vegna pess að stjórnunarsætunum er skipt á milli peirra einstaklinga sem fara með stærstu eignarhluti í félögum. ${ }^{13}$ Pessi sýn kann að breytast á næstu árum ef vilji er fyrir hendi að bæta leikreglur um eignarhald fyrirtækja og stjórnarhætti peirra.

\section{Rannsókn um áhrif kvenna í stjórnum fyrirtækja}

Megintilgangur rannsóknarinnar er að skoða samband kvenna í stjórn og ákveðinna pátta í stjórnarháttum innan fyrirtækja annars vegar og tengsl kvenna við arðsemi fyrirtækja hins vegar.

Í fyrsta lagi var lögð könnun fyrir æðstu stjórnendur af báðum kynjum í íslenskum fyrirtækjum. Markmiðið með könnuninni var að fá svör við pví hvort munur væri á hegðun peirra í starfi og hvort pau upplifðu stjórnarhætti innan fyrirtækisins er lytu að starfi peirra, á sama hátt eða ekki. ${ }^{14}$ Hér á eftir verður rætt um jákvæða stjórnarhætti pegar hvorugt kynið upplifir m.a. hindranir (glerpak) eða ójafnrétti í stjórnarháttum en neikvæða ef annað kynið eða bæði upplifa pað. Hluti svaranna úr könnuninni var síðan notaður til að meta hvort konur í stjórn hafi jákvæð áhrif á stjórnarhætti fyrirtækis. Í öðru lagi var gerð athugun á pví hvort pau fyrirtæki sem hafa jafnara kynjahlutfall í stjórnum séu líklegri til pess að hafa fleiri konur í æðstu stjórnendastöðum. Í priðja lagi var gerð athugun á pví hvort að fyrirtæki par sem kynjahlutfallið er jafnara séu líklegri til pess að vera arðsamari en pau fyrirtæki sem eru með einsleitar stjórnir.

Eins og kom fram í inngangi hafa birst erlendar rannsóknir á pessu sviði en pó er ekki vitað um aðra rannsókn en pessa sem nær yfir öll stærstu fyrirtæki á landsvísu, upplýsingar um stjórnarhætti sem snúa að starfi stjórnenda og stjórnendastíl stjórnenda. Rannsóknin hefur pó sína annmarka. Í fyrsta lagi var ekki unnt að safna saman aftur í tímann upplýsingum um fjölda stjórnenda og aðra mikilvæga pætti um

12 Sjá umfjöllun í skýrslu iðnaðar- og viðskiptaráðuneytisins (Póranna Jónsdóttir, 2005).

13 Sjá umfjöllun í skýrslu iðnaðar- og viðskiptaráðuneytisins (Fóranna Jónsdóttir, 2005).

14 Hér er notast við skilgreiningu sem finna má í skýrslu Birgis Más Ragnarsonar (2004) en par segir: Stjórnunarhættir eru „Stefnumiðin sem stjórnun fyrirłækis er miðuð við, svo og helstu grunnreglur og rammar sem ákvarða samspil stjórnunareininga fyrirtækisins, eigendurnir svo og aðrir aðilar, sem verða fyrir beinum áhrifum af fjármálalegum og rekstrarlegum ráđstöfunum fyrirtækisins (í pessu samhengi vísað til peirra sameiginlega sem aðila er hagsmuna eiga að gæta í fyrirtækinu). Hagsmunaaðilarnir eru starfsfólk, lánardrottnar, heildsalar, viðskiptavinir og viðkomandi bæjareða sveitarfélag, o.fl.“ 
stjórnarhætti innan fyrirtækja. Í öðru lagi var ekki hægt að fá upplýsingar hvorki í nútíð né fortíð um t.d. menntun, reynslu o.fl. hjá einstaklingum sem sitja í stjórnum valinna fyrirtækja en slíkar upplýsingar geta verið mikilvægar við mat á arðsemi. Til pess að fá sem bestar niðurstöður og með tilliti til pessara annmarka var ákveðið að hanna tvö gagnasöfn: Annars vegar par sem skoðuð eru gögn yfir eitt ár, p.e. um stjórnir, stjórnarhætti og stjórnendur (gagnasafn 1) og hins vegar gögn sem taka yfir tímabilið 2003 til 2006 til að greina arðsemi fyrirtækja (gagnasafn 2). Flestar rannsóknir sem hafa verið gerðar á arðsemi fyrirtækja ná aðeins yfir eitt ár og hafa pær verið gagnrýndar fyrir pað, m.a. vegna pess að eðlilegt er að gera ráð fyrir töfum frá pví að ákvörðun er tekin og par til hún skilar sér inn í efnahagsreikning.

\subsection{Viðhorfskönnun meðal stjórnenda}

Könnun var send út til 617 æðstu stjórnenda í 119 fyrirtækjum sem eru með innlenda framleiðslu og/eða selja vöru sína á erlendum mörkuðum. Fyrirtækin voru valin af lista Frjálsrar verslunar 2006 yfir 300 stærstu fyrirtæki á Íslandi. Gagnaöflun fór fram í gegnum tölvupóst á tímabilinu frá maí til júní 2008. Í heild tóku 269 stjórnendur pátt í könnuninni eða 44\%. Í ljós kom við gagnavinnslu að fjarlægja purfti 36 pátttakendur til að gæta samræmis milli gagnasafnanna eins og fjallað verður nánar um í lið 4.2. ${ }^{15}$ Alls voru pví notuð 101 fyrirtæki og svörun frá 236 pátttakendum eða $40 \%$ af heildarúrtaki. Par af voru 74 konur sem jafngildir 32\% af öllum pátttakendum. Hafa parf í huga að skipurit geta verið ólík eftir fyrirtækjum, p.e.a.s. hvernig æðstu stjórnendur eru skilgreindir. Í stærri fyrirtækjum er algengt að margir starfi sem framkvæmdastjórar og einn forstjóri en í minni fyrirtækjum er oftast einn framkvæmdastjóri eða forstjóri og næst á eftir honum t.d. sviðsstjórar eða deildarstjórar. Í rannsókninni var ákveðið að skilgreina æðstu stjórnendur í samræmi við pessa skiptingu hjá stærri og smærri fyrirtækjum enda ætti ábyrgðin að vera sú sama gagnvart fyrirtækinu. Pá parf að hafa í huga að ekki er vitað um bakgrunn peirra sem svöruðu ekki könnuninni en pað er alltaf hætta á að peir séu ólíkir peim sem svara könnunum.

Meðalaldur stjórnenda var 42 ár sem er í takt við mælingar Hagstofu Íslands á aldri framkvæmdastjóra. Eins var lítill munur á aldri eftir kyni. Konur höfðu almennt skemmri starfsaldur sem stjórnendur en karlmenn í fyrirtækinu eða að meðaltali um 5 ár á móti 7 árum hjá karlmönnum. Í tæknifyrirtækjum, fjármálapjónustu og annarri starfsemi ${ }^{16}$ var hlutfall kvenna um $25-35 \%$ en í frumvinnslu um $8 \%$. Í gögnum frá Hagstofunni eru konur í fjármálapjónustu svo dæmi sé tekið um 10\% sem er talsvert lægra en pessi athugun sýnir. Gera má pví ráð fyrir að hlutfallslega fleiri konur en karlar sem starfa í fjármálageiranum hafi svarað könnuninni. Í athugunum á stjórnendum og starfsemi í dönsku og bandarísku samfélagi kom í ljós að mjög fáir kven-

\footnotetext{
15 Peir einstaklingar sem voru fjarlægðir úr gagnasafninu svöruðu ekki könnuninni samkvæmt beiðni eða voru ekki peir stjórnendur sem leitað var eftir.

16 „Önnur starfsemi“ samanstendur af matvæla,- bygginga,- og fataframleiðslustarfsemi.
} 
Tafla 1. Bakgrunnur pátttakenda

\begin{tabular}{|c|c|c|c|}
\hline Pátttakendur & $\begin{array}{r}\text { Fjöldi } \\
236\end{array}$ & $\begin{array}{r}\text { Konur } \\
76(32 \%)\end{array}$ & $\begin{array}{r}\text { Karlar } \\
160(68 \%)\end{array}$ \\
\hline \multicolumn{4}{|l|}{ Aldur } \\
\hline 39 ára og yngri & 99 & $51 \%$ & $39 \%$ \\
\hline 40-49 ára & 99 & $44 \%$ & $41 \%$ \\
\hline 50 ára og eldri & 38 & $5 \%$ & $20 \%$ \\
\hline Samtals & 236 & $100 \%$ & $100 \%$ \\
\hline Meðalaldur & 42 ár (std. 8) & $40 a ́ r$ & $44 a ́ r$ \\
\hline \multicolumn{4}{|l|}{ Menntun } \\
\hline Ekki háskólagráđa & 24 & $8 \%$ & $10 \%$ \\
\hline Háskólagráða & 212 & $92 \%$ & $90 \%$ \\
\hline Samtals & 236 & $100 \%$ & $100 \%$ \\
\hline \multicolumn{4}{|l|}{ Starfsaldur } \\
\hline 1-4 ár & 103 & $57 \%$ & $40 \%$ \\
\hline 5-9 ár & 72 & $32 \%$ & $30 \%$ \\
\hline 10 ár eða lengur & 61 & $11 \%$ & $30,00 \%$ \\
\hline Samtals & 236 & $100 \%$ & $100 \%$ \\
\hline Meðalstarfsaldur & 8 ár (std. 7) & $5 a ́ r$ & $7 a ́ r$ \\
\hline \multicolumn{4}{|l|}{ Starfsemi } \\
\hline Frumvinnsla & 36 & $8 \%$ & $18 \%$ \\
\hline Fjármálapjónusta & 70 & $29 \%$ & $30 \%$ \\
\hline Tæknifyrirtæki & 69 & $29 \%$ & $29 \%$ \\
\hline Annað & 61 & $34 \%$ & $23 \%$ \\
\hline Samtals & 236 & $100 \%$ & $100 \%$ \\
\hline \multicolumn{4}{|l|}{ Stjórnunarreynsla } \\
\hline Já & 119 & $54 \%$ & $49 \%$ \\
\hline Nei & 117 & $46 \%$ & $51 \%$ \\
\hline Samtals & 236 & $100 \%$ & $100 \%$ \\
\hline \multicolumn{4}{|c|}{ Situr í stjórn fyrirtækis } \\
\hline Já & 122 & $39 \%$ & $60 \%$ \\
\hline Nei & 114 & $61 \%$ & $40 \%$ \\
\hline Samtals & 236 & $100 \%$ & $100 \%$ \\
\hline
\end{tabular}

Taflan sýnir fjölda pátttakenda og bakgrunn peirra eftir kyni í prósentum, flokkuð eftir aldri peirra, menntun, starfsaldri, starfsemi, stjórnunarreynslu og hvort pau sætu í stjórn fyrirtækis (ekki pó endilega í fyrirtækinu sem pau starfa hjá). 
stjórnendur störfuðu í frumiðnaði eða innan við 5\%. ${ }^{17}$ Ef frumiðnaðurinn í gögnunum er eingöngu skoðaður pá störfuðu 15\% pátttakenda par og par af voru konur um 30\%. Hugsanlegt er að pað sama eigi við hér og að ofan að fleiri konur svöruðu könnuninni eða pá, að fleiri konur eru í stjórnendastöðum í frumvinnslu hér á landi í samanburði við pessi tvö lönd. Mun algengara var að karlkyns stjórnendur sæu í stjórn fyrirtækja en kvenkyns stjórnendur eða 60\% karlmanna á móti 39\% kvenna. Par af sögðust 42\% karlmannanna vera stjórnarformenn í a.m.k. einu félagi en 19\% kvenna sögðu pað sama. Pá reyndist ekki vera munur á kynjunum eftir pví hvernig pau voru ráðin til starfa sem stjórnendur. Meirihlutinn sagðist ekki hafa verið ráðinn vegna beinna tengsla við fyrirtækið. Um 68\% karlkyns stjórnenda sögðust hafa unnið sig upp í starfi eða pað hafi verið bent á pá og rúmlega 74\% kvenkyns stjórnenda sögðu pað sama. Fáir stjórnendur af báðum kynjum sögðust hafa verið ráðnir gegnum ráðningastofu, sjá viðauka 1 . Að lokum má nefna að $54 \%$ kvenna sögðust hafa unnið sem stjórnendur áður en pær réðu sig í núverandi stjórnendastarf og 49\% karla sögðu pað sama.

Í könnuninni voru pátttakendur líka spurðir út í ýmsa pætti er varða stjórnunarstíl peirra og viðhorf til stjórnarhátta fyrirtækisins. Markmiðið með spurningunum var að athuga hvort kynin hegðuðu sér á ólíkan hátt og hvort að bæði kynin upplifðu jöfn tækifæri innan fyrirtækisins. Hér er að finna helstu niðurstöðurnar:

- Fleiri kvenstjórnendur sögðust síður deila verkefnum til undirmanna en karlstjórnendur eða $62 \%$ á móti 39\% karla.

- Langflestir af báðum kynjum fengu mikið út úr pví að hrósa starfsmönnum og aðstoða pá í starfi.

- 36\% kvenna sögðust vilja ná lengra í starfi en 21\% karlar.

- Hlutfallslega fleiri konur eða $42 \%$ á móti $23 \%$ karla sögðust standa frammi fyrir hindrunum í starfi.

- Meirihluti allra svarenda var ánægður með jafnréttisstefnu fyrirtækisins en af peim sem svöruðu pví neitandi voru fleiri konur eða 29\% á móti 5\% karla.

- Meirihlutinn taldi sig eiga auðvelt með að mynda tengsl við aðra stjórnendur eða $57 \%$ kvenna og um $68 \%$ karla.

- 35\% kvenstjórnenda sögðust hafa meira fram að færa en fyrirtækið nýtti sér og 26\% karlstjórnenda svöruðu pví sama.

- Meirihluti svarenda, bæði konur og karlar, svöruðu pví að pau vildu ekki innleiða kynjakvóta í stjórnir fyrirtækja; 69\% kvenna svöruðu spurningunni neitandi og 97\% karlar. Geta má pess að nú liggur fyrir frumvarp til laga par sem hlutafélög skulu gæta að kynjahlutföllum í stjórnum. Ef frumvarpið verður sampykkt óbreytt verður fróðlegt að fylgjast með hvernig próunin verður í stjórnskipun og áhrif hennar á stjórnarhætti fyrirtækja í framtíðinni. 


\subsection{TengsI milli kyns og stjórnunarstíls}

Marktækur munur var á stjórnunarstíl kynjanna við einstakar spurningar í könnuninni. Vísbending er um að konur deili síður verkefnum til starfsmanna sinna og velji frekar að vinna sem mest sjálfar. Ekki var pó munur á kynjunum hvað varðar umhyggjusemi við starfsmenn sína - kvarði mældur út frá hrósi, aðstoð og hvatningu. Hins vegar komu fram marktæk tengsl milli kyns og hindrunar í starfi - kvarði mældur út frá vinnutíma, fjölskyldustefnu, starfsframa og pví að koma sér á framfæri. Enginn marktækur munur var á kynjunum varðandi pað hvort pau ættu auðvelt eða erfitt með að mynda tengsl við aðra stjórnendur. Eins var ekki munur á kynjunum pegar pau voru spurð út í pað hvort peim pætti erfitt að vera í samkeppni við aðra stjórnendur innan fyrirtækisins. Pá var ekki heldur munur á kynjunum varðandi áhættusækni - kvarði sem var mældur út frá nokkrum páttum um ákvarðanatöku, sjá nánar í viðhengi 2.

Ofangreindar niðurstöður eru sambærilegar við erlendar rannsóknir, sérstaklega hvað varðar að deila verkefnum og pær hindranir sem konur upplifa. Í rannsókn Catalyst um menningarmun á kynjunum við stjórnun og skynjun peirra ${ }^{18} \mathrm{kom}$ fram að bæði kynin töldu að konur úthlutuðu síður verkefnum en karlmenn. Pessi páttur er samt sem áður einn af mikilvægustu páttum til að ná árangri að peirra mati. Í sömu rannsókn kom fram að karlmenn skynjuðu konur sem mun umhyggjusamari en karla gagnvart undirmönnum sínum. Í pessari athugun kom hins vegar fram að karlmenn eru jafn líklegir og konur til að sýna umhyggju í starfi.

Mikið hefur verið fjallað um að karlmenn hafi verið áhættusæknari en konur í starfi sem hafi ekki gefið góða raun pegar horft er til pess vanda sem við stöndum frammi fyrir í dag. Рað er hugsanlegt að pað sé rétt nálgun en geta má pess að könnunin var lögð fyrir stjórnendur eftir að fjármálakreppan var byrjuð að gera vart við sig og viðtöl voru að birtast í fjölmiðlum um pennan pátt í sambandi við karlstjórnendur. Af pessari ástæðu má vel vera að karlmenn hafi verið meðvitaðri um stöðu sína og svarað samkvæmt pví eða pað sé einfaldlega ekki rétt að heimfæra, almennt, á alla karlmenn að peir séu áhættusæknari en konur pótt hægt sé að benda á einstaka aðila. Pá er eins mögulegt að spurningarnar hafi ekki uppfyllt nægilega vel mat á áhættusækni.

\subsection{Konur og stjórnarhættir}

Margir hafa haldið uppi peirri skoðun að til pess að fjölga konum í stjórn purfi að byrja á pví að fjölga peim í æðstu stjórnendastöðum. Að sama skapi hefur sú skoðun komið fram að fjölgun kvenna í stjórnum geti hvatt til framgangs kvenna í stjórnendastöðum innan fyrirtækja m.a. vegna pess að pær leggja sitt af mörkum til að gera starfsumhverfið vænlegra fyrir konur til að ná árangri.

18 Catalyst, 2006. 
Í pessu samhengi var ákveðið að gera athugun á pví hvort að fyrirtæki með fleiri konur í stjórn séu líklegri til pess að vera með fleiri kvenstjórnendur og jákvæðari stjórnarhætti, sbr. skilgreiningu í upphafi pessa kafla. Notuð eru sömu fyrirtæki og í könnuninni, sbr. lið 4.1. Upplýsingar um fyrirtækin, s.s. aldur peirra, fjöldi starfsmanna, fjöldi stjórnenda og stjórnarmenn eftir kyni voru fengnar hjá RSK, Creditinfo, af heimasíðum fyrirtækja og svörum stjórnenda úr könnuninni. Til pess að mæla fjölda kvenstjórnenda var búin til breyta sem er kölluð kvenstjórnandi. Hún inniheldur hlutfall kvenna í stjórnendastöðum og tekur gildið núll fyrir enga konu í stjórnendahópi og einn fyrir fullkomið jafnvægi milli kynja eða sem nemur svokallaðri 4060 reglu. ${ }^{19}$ Рað sama var gert fyrir fjölda kvenna í stjórn fyrirtækja og kallast sú breyta fjölbreytni. Par sem mun fleiri karlmenn voru í stjórn fyrirtækja var ákveðið að búa til gervibreytu sem skipt er út fyrir breytuna fjölbreytni til að meta hvort einhver skekkja sé í matinu og eins hvort ein kona skipti máli eða hvort fleiri konur purfi að vera í stjórn til pess að hafa áhrif. Pessi breyta er kölluð kona og tekur gildið 1 ef kona er í stjórn fyrirtækis en núll ef engin kona er í stjórn. Aldur stjórnenda var metinn par sem hugsanlegt er að fleiri konur séu stjórnendur par sem meðalaldurinn er lægri eða hærri og að sama skapi er hugsanlegt að stjórnarhættir séu frábrugðnir eftir aldursamsetningu stjórnenda. Aldur fyrirtækis er líka metinn par sem hann getur sagt til um hvort starfsumhverfi stjórnenda sé einsleitt eða fjölbreytt. Hugsanlegt er að fleiri en færri af litlum og eldri fyrirtækjum séu rótgróin og fátítt sé að skipta út stjórnendum. •að getur pýtt að færri konur séu par í stjórnendahlutverki enda eiga pær almennt mun skemmri sögu sem stjórnendur en karlmenn. Pá hafa nokkrar erlendar rannsóknir sýnt fram á að pað sé hætta á að kvenstjórnendur séu vanmetnir ${ }^{20}$ vegna pess að ákveðin starfsemi er líklegri til pess að vera vinveittari konum (e. female-friendly) en önnur starfsemi. ${ }^{21}$ Ákveðið var pví að flokka fyrirtækin eftir pví á hvaða markaði pau störfuðu: Tæknifyrirtæki, fjármálapjónusta, frumvinnsla og önnur starfsemi. ${ }^{22}$ Að lokum var búin til breyta sem kölluð er stjórnarhættir. Hún lýsir skoðunum kynjanna á stefnu fyrirtækisins og hvort pau standi frammi fyrir ákveðnum hindrunum sem stjórnendur. Breytan er á skalanum frá „mjög sammála“ (jákvæðir stjórnarhættir) til „,mjög ósammála“ (neikvæðir stjórnarhættir) og byggist á niðurstöðum úr könnuninni sem fjallað var um hér að framan. Stuðst var síðan við eftirfarandi tilgátur:

- Fyrirtæki með fjölbreyttari stjórn eru líklegri til pess að vera með fleiri kvenstjórnendur.

- Fyrirtæki með fjölbreyttari stjórn eru líklegri til pess að vera með jákvæðari stjórnarhætti.

Notuð var aðferð minnstu kvaðrat (OLS-mat) og búin til prjú líkön. Í fyrsta líkaninu var háða breytan kvenstjórnandi og megin skýribreytan kona, sjá dálk 1 í töflu 2. Í öðru

19 Fjölbreyttasti stjórnendahópurinn er pegar konur eru a.m.k. 40\% af heildarstjórnendum. Ef konur eru í meirihluta gildir sama og með meirihluta karla, p.e. prósentuhlutfallið stefnir í átt að núlli.

20 Du Rietz og Henreksen, 2000.

21 Sjá m.a. rannsóknir Carter, Simkins og Simpson, 2002; Smith, Smith og Vernen, 2005.

22 Önnur starfsemi er eins og fyrr segir matvæla-, bygginga-, og fataframleiðsla. 
lagi var notuð sama háða breytan en nú með óháðu breytunni fjölbreytni í stað konu, sjá dálk 2, p.e. til að athuga hvort pær purfi að vera fleiri en ein í stjórn til pess að hafa áhrif. Að lokum var búið til líkan með háðu breytunni stjórnarhættir, sjá dálk 3 og sömu skýribreytur notaðar og í dálk 1 en að auki með breytunni kvenstjórnandi. Jöfnuna má rita með eftirfarandi hætti og stendur Y fyrir kvenstjórnanda eða stjórnarhætti. ${ }^{23}$

$Y($ hád breyta $)=\beta_{1} X_{i}+\beta_{2} A_{i}+\beta_{3} J_{i}+\beta_{4} S_{i}+\beta_{5} G_{i}+\beta_{6} E_{i}+\beta_{7} P_{i}+\beta_{8} I_{i}+\varepsilon i$

Tafla 2. Tölfræðilikön um áhrif kvenna í stjórn fyrirtækja

\begin{tabular}{|c|c|c|c|}
\hline Breytur & $\begin{array}{l}\text { Í pessum dálk er háða } \\
\text { breytan } Y \\
\text { (kvenstjórnandi) keyrð } \\
\text { með óháðu breytunni } \\
\text { fjölbreytni }\end{array}$ & $\begin{array}{l}\text { Í pessum dálk er háða } \\
\text { breytan } Y \\
\text { (kvenstjórnandi) keyrð } \\
\text { með óháðu breytunni } \\
\text { kona }\end{array}$ & $\begin{array}{l}\text { Í pessum dálk er háða } \\
\text { breytan } Y \\
\text { (stjórnarhættir) keyrð } \\
\text { með óháðu breytunum } \\
\text { fjölbreytni og } \\
\text { kvenstjórnandi }\end{array}$ \\
\hline Fasti & $(1,72)^{*}$ & $(1,49)^{*}$ & $1,97 \quad(-2,11)^{* *}$ \\
\hline Fjölbreytni & & $(0,73)$ & $1,50 \quad(0,97)$ \\
\hline Kona $=1$ & $(0,96)$ & & \\
\hline Aldur & $(0,25)$ & $(0,45)$ & $(1,59)^{*}$ \\
\hline Starfsfjöldi & $-0,03 \quad(-1,19)$ & $-0,04 \quad(-1,81)^{*}$ & $-0,01 \quad(-1,53)^{*}$ \\
\hline Stjórnendafjöldi & $-0,37 \quad(-2,22)^{* *}$ & $(-3,19)^{* * *}$ & $-0,16 \quad(-0,46)$ \\
\hline Starfsaldur & $0,15 \quad(0,58)^{*}$ & $0,17 \quad(1,12)$ & $-0,17 \quad(-1,13)$ \\
\hline Aldur fyrirtækis & $-0,08 \quad(-1,23)$ & $-0,15 \quad(-1,40)^{*}$ & $0,03 \quad(1,70)^{*}$ \\
\hline \multicolumn{4}{|l|}{ Starfsemi } \\
\hline Tæknifyrirtæki & $-0,23 \quad(-0,87)$ & $(-1,02)$ & $(1,07)$ \\
\hline Fjármálapjónusta & $-0,25 \quad(-0,95)$ & $(-1,23)$ & $(1,20)$ \\
\hline Frumvinnsla & $-0,26 \quad(-1,26)$ & $(-1,42)^{*}$ & $(0,91)$ \\
\hline Annað & $-0,20 \quad(-0,74)$ & $(-1,06)$ & $(1,13)$ \\
\hline Kvenstjórnandi & & & $-0,07 \quad(-0,19)$ \\
\hline$R^{2}$ & 0,1 & 0,13 & 0,21 \\
\hline
\end{tabular}

Í hverjum dálk er fyrri talan stuðull og seinni talan T-gildi.

${ }^{*}$ Marktækt við 10\%. ** Marktækt við 5\%. ${ }^{* * *}$ Marktækt við 1\%.

Taflan sýnir að pað er jákvætt samband milli fjölda kvenstjórnenda og fjölbreytni í stjórn fyrirtækja pótt tengslin séu ekki marktæk, p.e. vísbending er um að pað eru ekki endilega fleiri kvenstjórnendur í fyrirtækjum par sem konur eru í stjórn pegar öðrum breytum er haldið föstum. Marktæk tengsl komu hins vegar fram við fjölda kvenstjórnenda og fjölda stjórnenda í fyrirtækinu, p.e. vísbending er um að fleiri kvenstjórnendur starfi í smærri fyrirtækjum par sem stuðullinn hefur mínus for-

23 Par sem $\beta$ er stikamat, $X_{i}$ er konur í stjórn fyrirtækja $i, \mathrm{~A}_{i}$ er aldur stjórnenda, $S_{i}$ er stærð fyrirtækis, $G_{i}$ er starfsaldur stjórnanda, $E_{i}$ er fjöldi starfsmanna, $P_{i}$ er fjöldi stjórnenda, $I_{i}$ er tegund starfsemi, $J_{i}$ er aldur fyrirtækis og $\varepsilon$ er afgangsliðir. 
merki. Ekki koma heldur fram marktæk tengsl milli fjölda kvenna í stjórn og stjórnarhátta sem er vísbending um að stjórnarhættir geta verið jákvæðir pótt ekki sé fjölbreytni í stjórn. Skýringargildið er pó lágt í öllum líkönunum sem getur stafað af pví að pað vanti aðra skýribreytu eða gögnin skýra ekkert meira en meðaltal gagnanna. Pó ber að hafa í huga að hlutfallið segir ekki mikið um líkanið sjálft, gæði niðurstaðna pess, og prátt fyrir lágt hlutfall geta niðurstöðurnar verið réttar. Á sama hátt benda niðurstöðurnar ekki til pess að áhrifin séu öfug, p.e. að fleiri konur sitji í stjórn par sem fleiri konur eru í stjórnendastöðum innan fyrirtækis, sjá greiningu í viðauka 3. Pó ber að hafa í huga að hér á landi hefur ekki verið mikil hefð fyrir pví að stjórnendur í fyrirtæki séu valdir til pess að sitja í stjórn pess, sérstaklega hvað varðar stór félög. Hér á landi hefur verið deilt á að fámennur hópur sitji um stjórnarsætin. Peir eignast hlut og fá sæti í staðinn. Petta er talinn leikur sem konur geta ekki tekið pátt í par sem pær fari ekki eins mikið fyrir fé og karlmenn.

\subsection{Konur og arðsemi fyrirtækja}

Í pessari athugun voru skoðuð sömu fyrirtæki og í gagnasafni 1 en nú yfir priggja ára tímabil eða frá árinu 2003 til ársins 2006. Arðsemi fyrirtækja var mæld út frá arðsemi eigin fjár (ROE) og heildareigna (ROA) en pessar tölur í efnahagsreikningum fyrirtækja eru pekktar mælieiningar í rannsókn sem pessari. ${ }^{24}$ Breyturnar fjölbreytni og kona voru notaðar á sama hátt og í gagnasafni 1. Hugsanlegt er að skekkja myndist vegna pess að eftirfylgni er mislöng milli einstaklinga (kona eða karl) í stjórn fyrirtækja, p.e. sumir peirra höfðu verið í stjórn allt tímabilið (2003-2006) en aðrir skemur. Til að leiðrétta petta misræmi var búin til breyta sem heitir tímalengd og fylgir hún árunum eftir með lægsta gildið ef einstaklingur (karl eða kona) sat í stjórn allt tímabilið en prír ef hann hafði aðeins setið í eitt ár. Einnig var tekið tillit til aldurs og stærðar fyrirtækis eins og áður. Aldur fyrirtækis getur haft pýðingu fyrir arðsemitölurnar. Gera má ráð fyrir að fleiri en færri af yngri fyriræækjum séu ekki eins verðmæt og eldri fyrirtæki par sem pau hafa enn ekki mikla reynslu á markaði, eru að byggja upp markaðsstöðu sína og líða oftar fyrir pað að vera með hærri fjármagnskostnað. ${ }^{25}$ Pá var stærð fyrirtækis mæld út frá virði fyrirtækis og fjölda starfsmanna en arðsemi er að jafnaði talin hafa jákvæð áhrif á stærð fyrirtækis vegna meiri markaðsítaka. ${ }^{26}$

Pótt tölfræðimatið geti gefið vísbendingu um að breytan fjölbreytni hafi áhrif á arðsemi fyrirtækja parf að huga að orsakasambandinu, ${ }^{27}$ p.e.a.s. hvort pað er möguleiki á pví að bæði kynin í stjórn hafi í raun áhrif á arðsemi fyrirtækisins eða eru arðsamari fyrirtæki líklegri til pess að fá konur í stjórn en pau fyrirtæki sem eru ekki

24 Sjá m.a. rannsóknir Catalyst, 2007; Randøy, Thomsen og Oxelheim 2006; Francoeur, Labelle og Sinclair-Desgagné, 2008. Pað er líka algengt að nota Tobin's q en vegna fámennra fyrirtækja á Íslandi á skráðum markaði var ákveðið að taka líka inn óskráð félög.

25 Smith, Smith og Verner, 2005.

26 Smirlock, Gilliam og Marshall, 1984.

27 Hermalin og Weisbach, 1991. 
eins arðsöm? ${ }^{28}$ Ef síðari spurningin á líka við, er ekki ljóst hvort að fjölbreytni skipti arðsemi fyrirtækja máli eða hvort pað orsakast af pví að pað vanti aðra pætti til að skýra út áhrifin. Í raun er eðlilegt að velta pví fyrir sér hvort pað sé aukinn fjöldi kvenna sem gerir fyrirtækin að betri fyrirtækjum eða hvort að árangursdrifin fyrirtæki sjái frekar ástæðu til að opna augun fyrir konum. Til að skoða pennan pátt var breytan starfsemi notuð sem stoðbreyta eða tæknifyrirtæki, fjármálapjónusta, frumvinnsla og önnur starfsemi en erfitt er að finna upplýsingar um stjórnir fyrirtækja sem geta stutt líkönin frekar. Hönnuð voru síðan líkön með ofangreindum breytum. Notað var OLS-mat og síðan aðferð stoðbreytu (IV-mat). Eftirfarandi tilgáta er sett fram:

-Fyrirtæki með fjölbreyttari stjórn eru líklegri til pess að skila meiri arðsemi.

Tafla 3 sýnir niðurstöður úr líkönunum, annars vegar par sem háða breytan er arðsemi, mæld út frá eigin fé og hins vegar af heildareignum. Jöfnuna má rita: ${ }^{29}$

$P_{i}(\operatorname{ardsemi})=\beta_{1} X_{i}+\beta_{2} T_{i}+\beta_{3} S_{i}+\beta_{4} J_{i}+\beta_{4} V_{i}+\varepsilon i$

$P_{i}($ ardsemi $)=\beta_{1} X_{i}+\beta_{2} T_{i}+\beta_{3} S_{i}+\beta_{4} J_{i}+\beta_{4} V_{i}+\delta I+\varepsilon i$

Taflan sýnir að pað eru marktæk jákvæð tengsl milli fjölbreytni og arðsemi eigin fjár, p.e. fyrirtæki sem hafa bæði kynin í stjórn eru líklegri til pess að skila betri arðsemi. Fylgnistuðullinn mælist á bilinu $80-87 \%{ }^{30}$ Tilgátunni er pví ekki hafnað. Pví meiri sem fjölbreytni (jafnara hlutfall milli kynja) er innan stjórnar fyrirtækis, pví meiri líkur eru á arðsemi eigin fjár pegar öðrum stærðum er haldið föstum. Að sama skapi er jákvætt samband milli fjölbreytni og arðsemi heildareigna en tengslin eru mjög veik og pví erfitt að álykta um matið. Stuðlarnir mældust á bilinu 4-5\%. Áhrifin í líkönunum virðast ekki vera viðkvæm fyrir matsaðferðinni pví stuðlarnir eru svipaðir pegar sett var inn gervibreyta fyrir konur í stað fjölbreytni en tengslin urðu veikari. Skýringargildið $R^{2}$ er hins vegar fremur lágt við öll möt. Önnur leið til pess að skoða hugsanleg áhrif er að snúa forsendunum við og nota fjölbreytni (bæði kynin) í stjórn sem háða breytu, sjá viðhengi 4.

28 Ástæðurnar fyrir pví að arðsamari fyrirtæki skipa bæði kynin í stjórn geta verið af ýmsum toga. Sem dæmi má nefna að bæta ímynd sína útá við, sbr. hagsmunakenninguna en ákvarðanirnar geta samt sem áđur verið einsleitar eða pau sjá verðmæti í pví að skipa bæði kynin í stjórn fyrirtækisins.

29 Par sem $\beta$ eru metnir stuðlar, $X_{i}$ er konur í stjórn í fyrirtækis $i, T_{i}$ er tímalengd í stjórn, $S_{i}$ er mæld sem stærð fyrirtækis, $J_{i}$ er aldur fyrirtækis, $V_{i}$ er virði fyrirtækis, $\delta I$ er stoðbreyta og $\varepsilon$ eru afgangsliðar.

30 Reiknað sem $\exp (\beta)-1$, par sem $\beta$ er stikamatið. 
Tafla 3. Tölfræðileg líkön um arðsemi fyrirtækja

\begin{tabular}{|c|c|c|c|c|c|c|c|c|}
\hline \multirow[b]{2}{*}{ Breytur } & \multicolumn{4}{|c|}{$\begin{array}{l}\text { Í pessum tveimur dálkum er háða } \\
\text { breytan } P \text { keyrð með óháðu } \\
\text { breytunni fjölbreytni }\end{array}$} & \multicolumn{4}{|c|}{$\begin{array}{l}\text { Í pessum tveimur dálkum er háda } \\
\text { breytan } P \text { keyrð með óháðu } \\
\text { breytunni kyn }\end{array}$} \\
\hline & & OLS & & VI & & OLS & & VI \\
\hline \multicolumn{9}{|c|}{ Háða breyta: Arðsemi eigin fjár } \\
\hline Fasti & 0,18 & $(0,75)$ & 0,11 & $(1,07)$ & 0,21 & $(0,88)$ & 0,08 & $(0,62)$ \\
\hline Fjölbreytni & 0,59 & $(3,10)^{* * *}$ & 0,63 & $(3,46)^{* * *}$ & & & & \\
\hline Kona & & & & & 0,53 & $(1,75)^{* *}$ & 0,36 & $(1,83)^{* *}$ \\
\hline Aldur & $-0,02$ & $(-0,73)$ & $-0,07$ & $(-1,00)$ & $-0,01$ & $(-0,24)$ & $-0,02$ & $(-0,35)$ \\
\hline lnStærð & $-0,11$ & $(-0,65)$ & $-0,13$ & $(-1,07)$ & $-0,10$ & $(-0,29)$ & $-0,19$ & $(-0,22)$ \\
\hline Tímalengd & 0,14 & $(0,82)$ & 0,41 & $(0,31)$ & 0,44 & $(0,51)$ & 0,32 & $(0,09)$ \\
\hline $\operatorname{lnVirði}$ & $-0,21$ & $(-0,47)$ & $-0,03$ & $(-0,96)$ & $-0,18$ & $(-0,49)$ & $-0,03$ & $(-0,35)$ \\
\hline \multicolumn{9}{|l|}{ Starfsemi: } \\
\hline Tæknifyrirtæki & & & $-0,06$ & $(-0,39)$ & & & $-0,03$ & $(-0,22)$ \\
\hline Fjármálapjónusta & & & 0,02 & $(0,31)$ & & & 0,02 & $(0,30)$ \\
\hline Frumvinnsla & & & $-0,38$ & $(-1,11)$ & & & $-0,15$ & $(-1,16)$ \\
\hline Annað & & & 0,29 & $(0,86)$ & & & 0,17 & $(1,35)^{*}$ \\
\hline$R^{2}$ & 0,39 & & 0,41 & & 0,3 & & 0,33 & \\
\hline \multicolumn{9}{|c|}{ Háða breyta: Arðsemi heildareigna } \\
\hline$\overline{\text { Fasti }}$ & 0,12 & $(0,46)$ & 0,11 & $(0,62)$ & 0,05 & $(0,21)$ & 0,14 & $(0,64)$ \\
\hline Fjölbreytni & 0,06 & $(1,70)^{* *}$ & 0,05 & $(1,44)^{*}$ & & & & \\
\hline Kona & & & & & 0,06 & $(1,69)^{* *}$ & 0,04 & $(1,34)^{*}$ \\
\hline Aldur & $-0,02$ & $(-0,36)$ & $-0,01$ & $(-0,25)$ & $-0,01$ & $(-0,23)$ & $-0,01$ & $(-0,19)$ \\
\hline lnStærð & $-0,13$ & $(-0,29)$ & 0,22 & $(1,16)$ & $-0,12$ & $(-0,28)$ & 0,23 & $(1,14)$ \\
\hline Tímalengd & 0,19 & $(1,01)$ & 0,24 & $(1,36)^{*}$ & 0,16 & $(1,02)$ & 0,21 & $(0,18)$ \\
\hline $\operatorname{lnVirði}$ & 0,02 & $(0,86)$ & 0,02 & $(0,86)$ & 0,03 & $(0,49)$ & 0,02 & $(0,86)$ \\
\hline \multicolumn{9}{|l|}{ Starfsemi: } \\
\hline Tæknifyrirtæki & & & $-0,04$ & $(-0,33)$ & & & $-0,05$ & $(-0,40)$ \\
\hline Fjármálapjónusta & & & 0,02 & $(0,27)$ & & & 0,02 & $(0,26)$ \\
\hline Frumvinnsla & & & $-0,05$ & $(-0,43)$ & & & $-0,06$ & $(-0,47)$ \\
\hline Annað & & & 0,05 & $(0,47)$ & & & 0,05 & $(0,40)$ \\
\hline$R^{2}$ & 0,37 & & 0,39 & & 0,29 & & 0,29 & \\
\hline
\end{tabular}

Fyrri talan í hverjum dálk er stuðull og síðari talan T-gildi.

* Marktækt við 10\%. ** Marktækt við 5\%. ${ }^{* * *}$ Marktækt við 1\%. 


\section{Niðurstöður}

Niðurstöðurnar benda til pess að lítill munur sé á stjórnunarstíl kynjanna nema hvað varðar einstaka pætti sem snúa að undirmönnum peirra. Karlmenn virðast vera mun duglegri að dreifa verkefnum í stað pess að vinna pau sjálfir. Á móti virðast kynin bæði leitast við að sýna undirmönnum sínum umhyggju sem talinn er góður kostur. Ástæðan fyrir pví að konur deila síður verkefnum til undirmanna getur verið sú að pær telja sig purfa að sinna sem flestum verkum sjálfar til pess að sýna ábyrgð og ná árangri. •að felur hins vegar ekki endilega í sér kosti vegna pess að hættan er sú að pað getur veikt liðsandann og sköpunarvilja í fyrirtækinu.

Pegar skoðuð voru viðhorf stjórnenda til stjórnarhátta fyrirtækja, kom í ljós að konur virðast ekki í öllum tilvikum upplifa sömu tækifæri og karlmenn til að ná árangri og reka sig oftar á hið svokallaða glerpak. Staða karlstjórnenda styður petta par sem fleiri af peim sögðust m.a. sitja í stjórn prátt fyrir að peir hafi ekki haft lengri stjórnunarreynslu en konur, meiri menntun eða verið eldri.

Í fyrri greiningunni kom fram að pað væri ekki munur á stjórnarháttum fyrirtækja eftir pví hvort fleiri konur sætu í stjórnum fyrirtækja eða væru par í stjórnendastöðum. Í seinni greiningunni kom fram vísbending um tengsl arðsemi og fjölda kvenna í stjórnum fyrirtækja sem er í samræmi við margar erlendar rannsóknir. Ekki skiptir máli hvort um var að ræða jafnara hlutfall milli kynja í stjórnum eða að a.m.k. ein kona sæti í hverri stjórn. Pá er vakin athygli á pví að niðurstöðurnar benda til pess að mun sjaldgæfara væri að konur sætu í stjórn fyrirtækja par sem starfandi væru fleiri stjórnendur og starfsmenn.

pegar niðurstöðurnar eru dregnar saman má álykta sem svo að pað eru í fyrsta lagi vísbendingar um að konur í stjórnum skipta fyrirtæki máli og par með hagsmuni hluthafa. Í öðru lagi eru vísbendingar um að konur eigi lengra í land með að ná áhrifum hvað varðar stjórnarhætti innan fyrirtækja. Í pessari rannsókn voru notaðar fleiri breytur en í mörgum erlendum rannsóknum en niðurstöðurnar eru pó pær sömu, p.e. að konum hefur ekki fjölgað í stjórnum með auknum hlut kvenna í stjórnendastöðum. Ástæðan getur verið sú að konur hafa verið mun skemur í stjórnum en karlmenn og breytingar innan fyrirtækja geta tekið sinn tíma eða að erfitt sé að rugga bátnum, p.e. hvað varðar stjórnskipun innan fyrirtækja. Önnur ástæða sem má nefna er að konur beiti sér enn ekki nægilega mikið fyrir að benda á kynsystur sínar og gera starfsumhverfi fyrirtækja vænlegra fyrir pær. Skýringargildið var pó frekar lágt í öllum athugunum. Pað getur pýtt að aðra pætti vanti inn í líkönin og pví mikilvægt að hægt verði í framtíðinni að nálgast frekari gögn um samsetningu stjórna, s.s. aldur stjórnarmanna, menntun peirra og starfsreynslu. Enn fremur að hægt verðiað greina betur stjórnendur og skipulagsheildir innan fyrirtækja. Pessir pættir geta hugsanlega bætt forspárgildið og gefið betri vísbendingu um hvað pað er sem hindrar framgang kvenna í forystuhlutverkum og hvað pað er sem veldur pví að konur bæta afkomu fyrirtækja. Að lokum má nefna pá vísbendingu að konur virðast ólíklegri til pess að hafa setið í stjórn í stærri fyrirtækjum par sem starfandi eru fleiri stjórnendur og 
starfsmenn. Skoða mætti pessa niðurstöðu nánar í sambandi við hrun stærri fyrirtækja í íslensku viðskiptalífi.

\section{Lokaorð}

Pegar petta er skrifað er verið að takast á við afleiðingar fjármálakreppunnar eins og fram kom í inngangi. Erfitt er að segja til um hvernig eignarhlutir í fyrirtækjum munu dreifast á næstu árum eða hvernig stjórnskipunum verður háttað. Stjórnir og stjórnendur ættu pó við pessar aðstæður að nýta sér tækifærið og fjölga konum í æðstu stjórnendastöðum og stjórnum enda margt sem bendir til pess að pær ýti undir meiri arðsemi en ef um einsleita stjórn er að ræða. Ekki ættu pví hlutafélög að óttast framlag peirra. Í greininni var fjallað um að konur væru ekki eins sýnilegar og karlmenn. Ef pað reynist rétt, mætti auka sýnileika kvenna með pví að taka upp svokallað mentorkerfi sem pekkist víða erlendis. Markmiðið með slíku kerfi yrði að pjálfa stjórnendur af báđum kynjum til pess að læra að stýra fyrirtækjum og stuðla pannig að pví að fleiri einstaklingar tækju að sér setu í stjórnum. Á sama hátt er pað ein leið til pess að ná fram meiri dreifingu í eignarhaldi fyrirtækja.

\section{Um höfundinn}

Margrét Sæmundsdóttir er hagfræðingur í viðskiptaráðuneytinu. Netfang: margret.saemundsdottir@vrn.stjr.is.

\section{Heimildaskrá}

Anastasopoulos, V., Brown, D.A.H. og Brown, D.L. (2002). „Women on boards: not just the right thing ... but the ,bright' thing." Report for the Conference Board of Canada. Slóð: http://www.conferenceboard.ca/documents.aspx?DID=374.

Birgir Már Ragnarsson (2004). „,Stjórnarhættir fyrirtækja.“ Skýrsla unnin fyrir iðnaðar- og viðskiptaráðuneyti af Lex ehf. Lögmannsstofu. Slóð: http://www.althingi.is/altext/130/s/pdf/1308.pdf.

Carter, D.A., Simkins, B.J. og Simpson, W.G. (2002). „Corporate governance, board diversity, and firm value." Financial Review 38 (1), 33-53.

Catalyst (2006). Different cultures, similar perceptions: stereotyping of western European business leaders. Slóð: http://www.catalyst.org/file/42/different\%20cultures, \%20similar \%20perceptions\%20stereotyping\%20of\%20western\%20uropean\%20business $\%$ 20leaders.pdf.

Catalyst (2007). „2006 Catalyst census of women corporate officers and top earners of the Fortune 500.“ Slóð: http://www.catalyst.org/file/8/cote.pdf.

Catalyst (2008). „2008 Catalyst census of women board directors of the Fortune 500.“ Slóð: http://www.catalyst.org/file/242/08_census_wbd_jan.pdf.

Dewatripont, M., Jewitt, I. og Tirole, J. (1999). „The economics of career concerns, part II: application to missions and accountability of government agencies." Review of Economic Studies 66 (1), 199-217. 
Donaldson, T. og Preston, L. (1995). „The stakeholder theory of the corporation: concepts, evidence, and implications." Academy of Management Review 20 (1), 65-91.

Du Rietz, A. og Henrekson, M. (2000). „Testing the female underperformance hypothesis.“ Small Business Economics, 14 (1), 1-10.

European Commission (2003). „The cost and benefits of diversity: a study on methods and indicators to measure the cost-effectiveness of diversity policies in enterprises."

Executive summary. Directorate-General for Employment, Industrial Relations and Social Affairs, Unit D/3. Slóð: http://www.stop-

discrimination.info/fileadmin/pdfs/CostsBenefExSumEN.pdf.

Fields, M.A. og Keys, P. Y. (2003). „,The emergence of corporate governance from Wall St. to Main St.: outside directors, board diversity, earnings management, and managerial incentives to bear risk." Financial Review 38 (1), 1-24.

Francoeur, C., Labelle, R. og Sinclair-Desgagné, B. (2008). „Gender diversity in corporate governance and top management." Journal of Business Ethics 81 (1), 83-95.

Hagstofa Íslands (2008). Tafla um kyn framkvæmdastjóra og stjórnarmanna eftir stærð fyrirtækja. Hagtölur frá Hagstofu Íslands undir aðalflokk 4 um fyrirtæki og veltu. Sótt af heimasíðunni www.hagstofan.is pann 30. ágúst 2008.

Hambrick, D.C., Cho, T.S. og Chen, M.J. (1996). „,The influence of top management team heterogeneity on firms' competitive moves." Administrative Science Quarterly 41, 659-684.

Hermalin, B.E. og Weisbach, M.S. (1991). „The effects of board composition and direct incentives on firm performance." Financial Managment, 20 (4), 101-112.

Jafnréttiskennitalan (2008). „Jafnréttiskennitalan: birting upplýsinga um jafnrétti i 100 stærstu fyrirtækjum á Íslandi árið 2007." Rannsóknasetur vinnuréttar og jafnréttismála, Háskólinn á Bifröst. Slóð: http://rvj.bifrost.is/Files/Skra_0019672.pdf.

Jurkus, A.F., Park. J.C. og Woodard, L.S. (2008). „Gender diversity, firm performance, and environment." Óbirt grein, Louisiana Tech University, Department of Economics and Finance. Slóð: http://ssrn.com/abstract=1085109.

Mace, M. (1971). Directors: myth and reality. Boston: Graduate School of Business Administration, Harvard University.

Milkovich, G.T. og Boudreau, J.W. (1997). Human resource management. 8. útg. Chicago: Irwin.

Milliken, F.J. og Martins, L.L. (1996). „Searching for common threads: understanding the multiple effects of diversity in organizational groups." Academy of Management Review 21(2), 402-433.

OECD (2009). „The corporate governance lessons from the financial crisis.“ Financial Market Trends 96. Slóð: http://www.oecd.org/dataoecd/32/1/42229620.pdf.

Randøy, T., Thomsen, S. og Oxelheim, L. (2006). A Nordic perspective on corporate board diversity. Oslo: Nordic Innovation Centre. Slóð: http://www.nordicinnovation.net /_img/a_nordic_perspective_on_board_diversity_final_web.pdf.

Rose, C. (2005). „Bestyrelsessammensætning og finansiel performance i børsnoterede virksomheder - belyst i et corporate governance perspektiv." Ledelse E Erhvervsøkonomi 69 (4), 215-230.

Sealy, R., Obe, S.V. og Singh V. (2008). The female FTSE report 2008: a decade of delay. Cranfield University School of Management, International Centre for Women Leaders. Slóð: http://www.hbosplc.com/community/The\%20Female\%20FTSE\%20Report\%202008\%20\%20A\%20Decade\%20of\%20Delay.pdf. 
Smirlock, M., Gilligan, T.W. og Marshall, W. (1984). „Tobin's q and the structure-performance relationship." American Economic Review 74 (5), 1051-1060.

Smith, N., Smith, V. og Verner, M. (2005). „Do women in top management affect firm performance? A panel study of 2500 Danish firms. " Forschungsinstitut zur Zukunft der Arbeit discussion paper no. 1708. Slóð: ftp://ftp.iza.org/dps/dp1708.pdf.

Póranna Jónsdóttir (2005). „Aukin tækifæri í forystu atvinnulífsins. Skýrsla Tækifærisnefndar iðnaðar- og viðskiptaráðherra um aukinn hlut kvenna í yfirstjórnum fyrirtækja.“ Iðnaðar- og viðskiptaráðuneyti, rit 05-03. Slóð:

http://www.idnadarraduneyti.is/utgefid-efni/skyrslur/nr/1718.

\section{Viðauki 1}

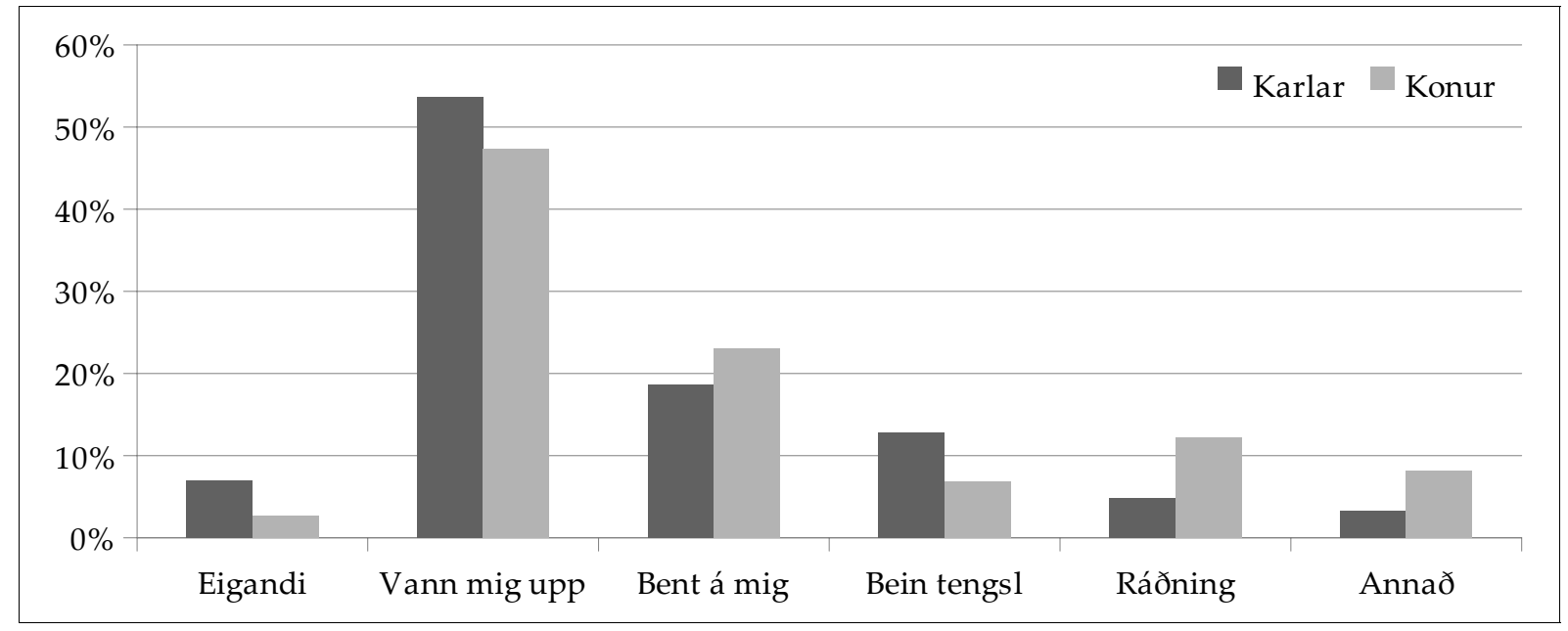

Spurning: Hvernig varstu rádin(n) í núverandi stjórnunarstöðu?

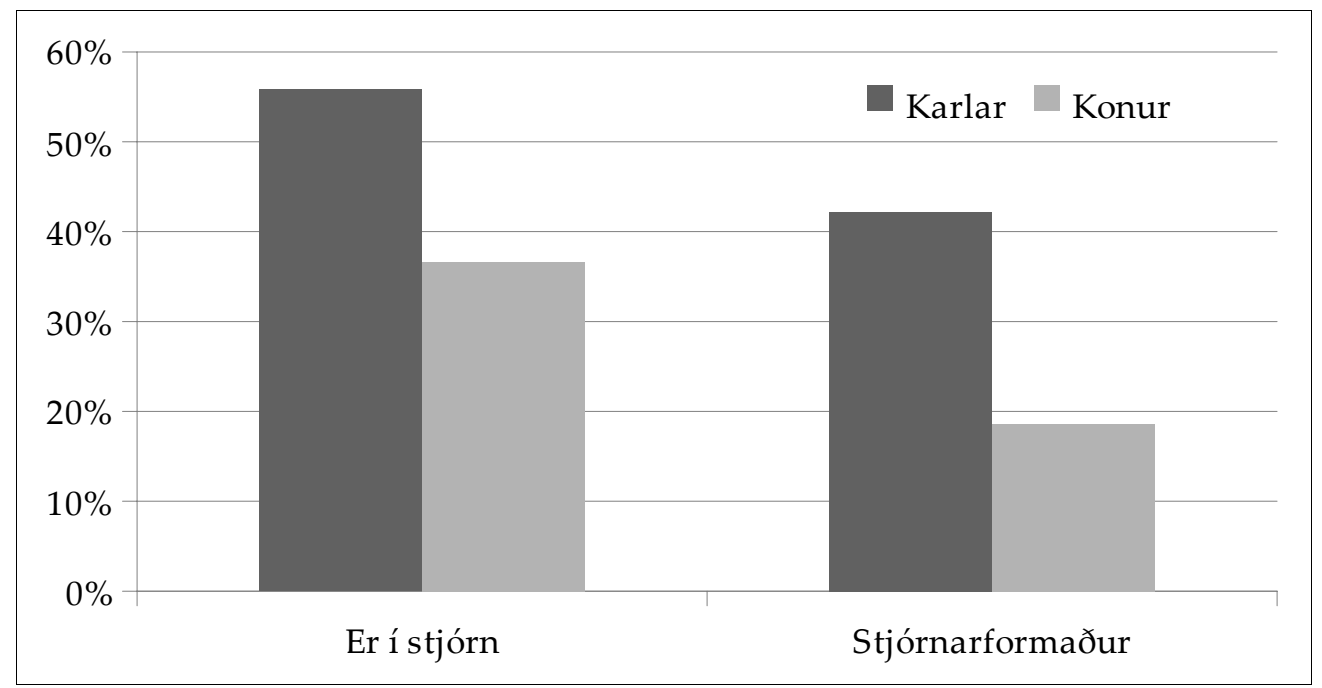

Spurning: Ertu i stjórn fyrirtækis? 


\section{Viðauki 2}

Lýsandi tölfræði og marktæknipróf fyrir tengsl kyns og niðurstaðna á svörun um stjórnarhætti innan fyrirtækja

\begin{tabular}{lllll}
\hline Breytur & Fjöldi & Meðaltal & Staðalfrávik & t-próf \\
\hline Samkeppni & 236 & 1,62 & 0,49 & $-1,70^{*}$ \\
Deila verkefnum & 236 & 0,40 & 0,49 & $-3,50^{* * *}$ \\
Hindrun & 236 & 1,67 & 0,48 & $3,01^{* *}$ \\
Áhættusækni & 236 & 1,76 & 0,43 & 0,80 \\
Tengsl & 236 & 1,84 & 0,37 & 1,08 \\
Umhyggja & 236 & 1,89 & 0,32 & $1,82^{*}$ \\
Jafnréttisstefna & 236 & 0,67 & 0,48 & $-3,55^{* * *}$ \\
\hline
\end{tabular}

${ }^{*} p<0,05 ;{ }^{* *} p<0,01 ;{ }^{* * *} p<0,001$. 


\section{Viðauki 3}

Í pessari greiningu eru búin til tvö líkön. Í fyrsta lagi eru gögnin keyrð með OLS-mati par sem háða breytan er fjölbreytni í stjórn fyrirtækja. Í öðru lagi eru gögnin keyrð með Logit - mati par sem háða breytan er gervibreytan kona. Jöfnuna má rita með eftirfarandi hætti:

$X_{i}($ fjölbreytni ístjórn $)=\beta_{1} y_{i}+\beta_{2} A_{i}+\beta_{3} j_{i}+\beta_{4} S_{i}+\beta_{5} G_{i}+\beta_{6} E_{i}+\beta_{7} P_{i}+\beta_{8} I_{i}+\varepsilon i$

Tölfræðilíkön um áhrif kvenstjórnenda á stjórn fyrirtækis

\begin{tabular}{|c|c|c|}
\hline Breytur & $\begin{array}{l}\text { Í pessum dálk er háða breytan } \\
(X) \text { fjölbreytni, OLS mat }\end{array}$ & $\begin{array}{l}\text { Í pessum dálk er háđa breytan } \\
(X) \text { kona, Logit mat }\end{array}$ \\
\hline Fasti & $0,05 \quad(1,97)^{*}$ & $0,15 \quad(0,07)$ \\
\hline Kvenstjórnandi & $(0,61)$ & $(0,08)$ \\
\hline Aldur & $(0,35)$ & $(0,04)$ \\
\hline \multicolumn{3}{|l|}{ Starfsemi } \\
\hline Tækni & $-0,17 \quad(-0,84)$ & $0,02 \quad(0,06)$ \\
\hline Fjármálapjónusta & $-0,22 \quad(-1,09)$ & $-0,17 \quad(-0,37)$ \\
\hline Frumvinnsla & $-0,24 \quad(-1,17)$ & $-0,68 \quad(-1,37)$ \\
\hline Annað & $-0,18 \quad(-0,87)$ & $-0,06 \quad(-0,14)$ \\
\hline Starfsaldur & $0,13 \quad(1,81)^{*}$ & $0,29 \quad(1,65)^{*}$ \\
\hline Starfsfjöldi & $0,00 \quad(-0,15)$ & $0,05 \quad(0,27)$ \\
\hline Stjórnendafjöldi & $-0,51 \quad(-3,33)^{* * *}$ & $-0,69(-1,85)^{* *}$ \\
\hline Aldur fyrirtækja & $-0,22 \quad(-0,67)$ & $0,34 \quad(1,06)$ \\
\hline Stjórnarhæettir & $0,10 \quad(0,30)$ & $0,08 \quad(0,73)$ \\
\hline$R^{2}$ & 0,38 & $78 \%$ rétt spá \\
\hline
\end{tabular}

Taflan sýnir að pað eru engin tengsl á milli fjölbreytni í stjórn og kvenstjórnenda í fyrirtækjum. Vísbending er pví um að fleiri konur í stjórnendahópi leiði ekki til fjölgunar kvenna í stjórnum. Marktæk tengsl eru hins vegar milli fjölda stjórnenda og kvenna í stjórn, p.e. konur eru líklegri til pess að vera í stjórn fyrirtækja par sem eru færri stjórnendur. Í hverjum dálk er fyrri talan stuðull og seinni talan T-gildi.

* Marktækt við 10\%. ${ }^{* *}$ Marktækt við 5\%. ${ }^{* * *}$ Marktækt við 1\%. 


\section{Viðauki 4}

Í pessari greiningu eru búin til fjögur líkön. Í dálk 1 eru gögnin keyrð með aðferð minnstu kvaðrat, OLS-mati par sem háđa breytan er fjölbreytni í stjórn fyrirtækja og megin skýribreytan er ROE (eigið fé). Í dálk 2 eru sömu gögn keyrð með háðu breytunni kona í stað fjölbreytni. Í dálkum 3 og 4 eru notaðar sömu háðu breytur og í dálk 1 og 2 en nú er megin skýribreytan ROA (heildareign). Jöfnuna má rita með eftirfarandi hætti:

$X_{i}($ fjölbreytni $)=\beta_{1} P_{i}+\beta_{2} T_{i}+\beta_{3} S_{i}+\beta_{4} J_{i}+\beta_{4} V_{i}+\delta I+\varepsilon i$

Tölfræðilíkön um arðsemi fyrirtækja

\begin{tabular}{|c|c|c|c|c|}
\hline \multirow{4}{*}{$\begin{array}{l}\text { Breytur } \\
\text { Fasti }\end{array}$} & \multicolumn{4}{|c|}{ 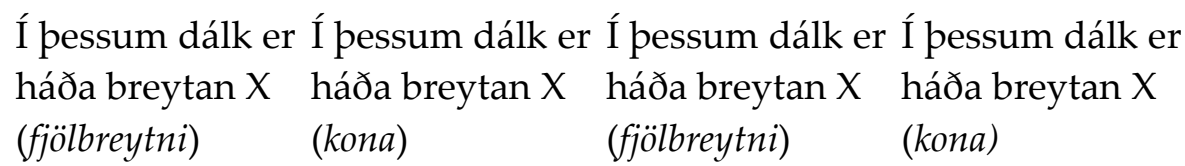 } \\
\hline & \multirow{2}{*}{$\begin{array}{l}\text { keyrð með ROE, } \\
\text { OLS-mat }\end{array}$} & \multirow{2}{*}{$\begin{array}{l}\text { keyrð með ROE, } \\
\text { Logit-mat }\end{array}$} & \multirow{2}{*}{\multicolumn{2}{|c|}{$\begin{array}{l}\text { keyrð með ROA, keyrð með ROA, } \\
\text { OLS-mat } \quad \text { Logit-mat }\end{array}$}} \\
\hline & & & & \\
\hline & $(1,12)$ & $(1,01)$ & $(1,07)$ & $\begin{array}{ll}0,93 \quad(1,02) \\
\end{array}$ \\
\hline Aldur fyrirtækis & $-0,02 \quad(-0,88)$ & $-0,13 \quad(-0,57)$ & $(0,82)$ & $-0,13 \quad(-0,57)$ \\
\hline $\operatorname{lnStærð~}$ & $-0,12 \quad(-1,29)^{*}$ & $-0,22 \quad(-1,78)^{*}$ & $(2,11)^{* *}$ & $-0,29(-1,79)^{*}$ \\
\hline Tímalengd & $-0,31 \quad(-0,58)$ & $0,38 \quad(-0,01)$ & $-0,19 \quad(-0,60)$ & $-0,17 \quad(-0,01)$ \\
\hline $\operatorname{lnVirði}$ & $(1,46)$ & $0,05 \quad(0,57)$ & $0,01 \quad(1,27)$ & $0,05 \quad(0,50)$ \\
\hline ROE & $(1,25)^{*}$ & $(1,96)^{*}$ & & \\
\hline $\mathrm{ROA}$ & & & $(1,17)$ & $(1,67)^{*}$ \\
\hline \multicolumn{5}{|l|}{ Starfsemi } \\
\hline Tækni & $-0,07 \quad(-0,73)$ & $-0,13 \quad(-0,17)$ & $-0,08 \quad(-0,68)$ & $-0,17 \quad(-0,28)$ \\
\hline Fjármálapjónusta & $-0,02 \quad(-0,84)$ & $-0,05 \quad(-0,65)$ & $-0,02 \quad(-0,82)$ & $-0,06 \quad(-0,50)$ \\
\hline Frumvinnsla & $0,07 \quad(1,74)$ & $0,13 \quad(1,02)$ & $0,06 \quad(1,47)$ & $0,14 \quad(0,87)$ \\
\hline Annað & $(1,92)^{*}$ & $(2,01)^{* *}$ & $(2,20)^{* *}$ & $(1,98)^{* *}$ \\
\hline$R^{2}$ & 0,08 & $68 \%$ rétt spá & 0,08 & $69 \%$ rétt spá \\
\hline
\end{tabular}

Taflan sýnir marktæk jákvæð tengsl milli arðsemi eigin fjár og fjölbreytni en tengslin eru mjög veik. Lítil sem engin tengsl komu fram á milli fjölbreytni og heildareigna. Arðsamari fyrirtæki eru pví síður líklegri til pess að skipa bæði kynin í stjórn. Eins komu fram marktæk tengsl milli stærðar fyrirtækis og annarrar starfsemi við fjölbreytni í stjórn. Fyrri talan í hverjum dálk er stuðull og síðari talan T-gildi.

${ }^{*}$ Marktækt við 10\%. ${ }^{* *}$ Marktækt við 5\%. ${ }^{* * *}$ Marktækt við 1\%. 